\title{
Comparative sensitivity and specificity of Typhidot and Typhidot-M tests in the diagnosis of Enteric fever in Malaysian children
}

\author{
K.E. Choo, T.M.E. Davis , A. Ismail, T.A. Tuan Ismail, W.N.W. Ghazali
}

\begin{abstract}
Abstrak
Suatu penelitian untuk mengetahui sensitivitas dan spesifisitas uji Typhidot dan Typhidot-M dalam mendiagnosis demam enterik pada anak-anak Malaysia telah dilakukan. Pasien dibagi dalam dua kelompok: (i) pasien dengan biakan darah dan/atau feses positif S. typhi danatau dengan gambaran klinis yang jelas untuk demam enterik; (ii) pasien dengan kedua biakan negatif dan dengan gambaran klinis atau bukti lain adanya demam oleh sebab lain. Hasilnya menunjukkan bahwa Typhidot maupun Typhidot-M sama sensitifnya dengan uji Widal. Uji Typhidot-M memiliki spesifisitas yang sedikit lebih tinggi daripada uji Typhidot; keduanya memiliki spesifisitas sekitar 10\% lebih baik daripada uji Widal. Data juga menunjukkan bahwa uji Typhidot-M mungkin dapat meningkatkan ketepatan diagnosis demam oleh sebab lain pada anak-anak, yang dibuktikan dengan perbaikan spesifitas. Baik uji Typhidot maupun Typhidot-M adalah alat bantu diagnosis yang cepat dan dapat diandalkan dalam penatalaksanaan demam enterik. Uji Typhidot-M mungkin lebih disukai daripada uji Typhidot dalam mengidentifikasi pasien yang menderita demam oleh sebab lain sementara ia dalam masa penyembuhan demam enterik.
\end{abstract}

\begin{abstract}
A study was carried out to compare the sensitivity and specificity of Typhidot and Typhidot-M tests in the diagnosis of enteric fever in Malaysian children. The patients were divided into two groups: (i) those who were blood and lor stool culture positive for S. typhi and/or who had clinical features strongly suggestive of enteric fever; (ii) those who were both culture - negative and had clinical or other evidence of another febrile illness. The results showed both Typhidot and Typhidot-M testswere as sensitive as Widal test. The Typhidot-M test had slightly greater specificity than the Typhidot test; both had around $10 \%$ better specificity than the Widal test. The data also suggest that the Typhidot-M test may, as evidenced by improved specificity, increase diagnostic accuracy for other febrile illnesses in children. The Typhidot and Typhidot-M are both prompt and reliable diagnostic aids in the management of enteric fever. The typhidot-M test may be more preferable to the orginal Typhidot test in identifying patients who develop other febrile illnesses whilst recovering from enteric fever.
\end{abstract}

\section{INTRODUCTION}

Enteric fever remains a common infection in tropical countries. Positive blood culture is the diagnostic gold standard; indirect tests such as the Widal may be useful. The 'Typhidot' is a recently developed serological test which detects antibodies to a $50 \mathrm{kD}$ outer membrane protein of $S$. typhi $i^{1,2}$. The Typhidot detects IgM and IgG within hours of sampling; it is at least as sensitive and specific as the Widal test in children 3. Because of persistence of antibody, a positive IgM

Departments of Paediatrics and Medical Microbiology and Parasitology, School of Medical Sciences, Universiti Sains Malaysia, Kubang Kerian, Kelantan, Malaysia;

University of Western Australia,

Department of Medicine, Fremantle Hospital, Fremantle,

Western Australia. within 4 months and/or a positive $\operatorname{IgG}$ within 7 months of documented or suspected enteric fever should be interpreted with caution ${ }^{4}$. The 'Typhidot-M' is a refinement of the Typhidot test, eliminating specific IgG antibody. This should allow improved differentiation between new and recent infection in an area of high enteric fever endemicity. The aim of this study was to determine the relative sensitivity and specificity of Typhidot and Typhidot-M tests in febrile Malaysian children from an area of high enteric fever endemicity.

\section{PATIENTS}

Children aged 1 month to 12 years admitted to General Hospital, Kota Bharu with fever were recruited into the study. The patients were divided into two groups: (i) those who were blood and or stool culture positive for $S$. typhi and/or who had clinical features strongly suggestive of enteric fever; (ii) those who 
were both culture-negative and had clinical or other evidence of another diagnosis. Informed consent was obtained from parent or guardian before study entry.

\section{METHODS}

Full clinical assessment was performed on all the studied children. Routine laboratory tests and cultures were taken from them. Other tests (e.g. radiology) were performed as indicated on clinical grounds. Standard culture methods for $S$. typhi ${ }^{3}$ were employed. The organism (S. typhi) was identified by means of biochemical/agglutination tests (Wellcome Reagents, UK). Widal tests were performed by using commercial kits (Wellcome Diagnostics). The Typhidot and Typhidot-M tests were performed in all patients on admission by using visual assessment of colour change (commercially-available kits). All the studied children had conventional inpatient treatment and were followed up.

\section{RESULTS}

A total of 135 children were admitted to the study, 62 (46\%) in Group (i) and 73 (54\%) in Group (ii). The sensitivity and specificity of Typhidot and Typhidot$\mathrm{M}$ used alone and in combination, and of the Widal test are shown in the Table. Both Typhidot and Typhidot-M tests were as sensitive as the Widal tests in the diagnosis of enteric fever. The Typhidot-M test had slightly greater specificity than the Typhidot test; both had around 10\% better specificity than the Widal test. Using the two tests in combination resulted in greater sensitivity but reduced specificity compared to when they were used alone.

Table 1: Sensitivity, specificity of Typhidot and Typhidot-M tests when alone and in combination, and of the Widal test in diagnosis of typhoid fever in 135 children

\begin{tabular}{lcccc}
\hline & Typhidot & Typhidot-M & Both & Widal \\
\hline Sensitivity & $90.3 \%$ & $90.3 \%$ & $95.2 \%$ & $91.9 \%$ \\
Specificity & $91.7 \%$ & $93.1 \%$ & $86.3 \%$ & $80.8 \%$ \\
tve pred value & $90.3 \%$ & $91.8 \%$ & $85.5 \%$ & $80.3 \%$ \\
-ve pred value & $91.8 \%$ & $91.9 \%$ & $95.5 \%$ & $92.2 \%$ \\
\hline
\end{tabular}

\section{DISCUSSION}

These data suggest that the Typhidot-M test allows detection of specific IgM to the $50 \mathrm{kD} S$. typhi outer membrane protein in children with enteric fever who may have a predominant IgG response. These data also suggest that the Typhidot-M test may, as evidenced by improved specificity, increase diagnostic accuracy for other febrile illnesses in children from a highly endemic area. This would be in the 'window period' between 4 and 7 months after enteric fever when IgM becomes negative but IgG remains positive in convalescent patients ${ }^{3}$.

\section{CONCLUSION}

The Typhidot and Typhidot-M tests are both prompt and reliable diagnostic aids in the management of enteric fever in children. The Typhidot-M test may be preferable to the original Typhidot test in identifying patients who develop other febrile illnesses whilst recovering from enteric fever. These findings confirm that the use of a diagnostic test depend on epidemiological context as well as on factors such as convenience and cost.

\section{REFERENCES}

1. Ismail A, Ong KH, Kader ZA. Demonstration of an antigenic protein specific for Salmonella typhi. Biochem Biophys Res Commun 1991; 181: 301-5.

2. Ismail A, Kader ZA, Ong KH. Dot enzyme immunosorbent assay for the serodiagnosis of typhoid fever. Southeast Asian J Trop Med Public Health 1991; 22: 563-6.

3. Choo KE, Oppenheimer SJ, Ismail AB, Ong KH. Rapid serodiagnosis of typhoid fever by dot enzyme immunoassay in an endemic area. Clin Infect Dis 1994; 19: 172-6.

4. Choo KE, Davis TME, Ismail A, Ong KH. Longevity of antibody responses to a Salmonella typhi-specific outer membrane protein: interpretation of a dot enzyme immunosorbent assay in an area of high typhoid fever endemicity. Am J Trop Med Hyg (in print) 1997. 